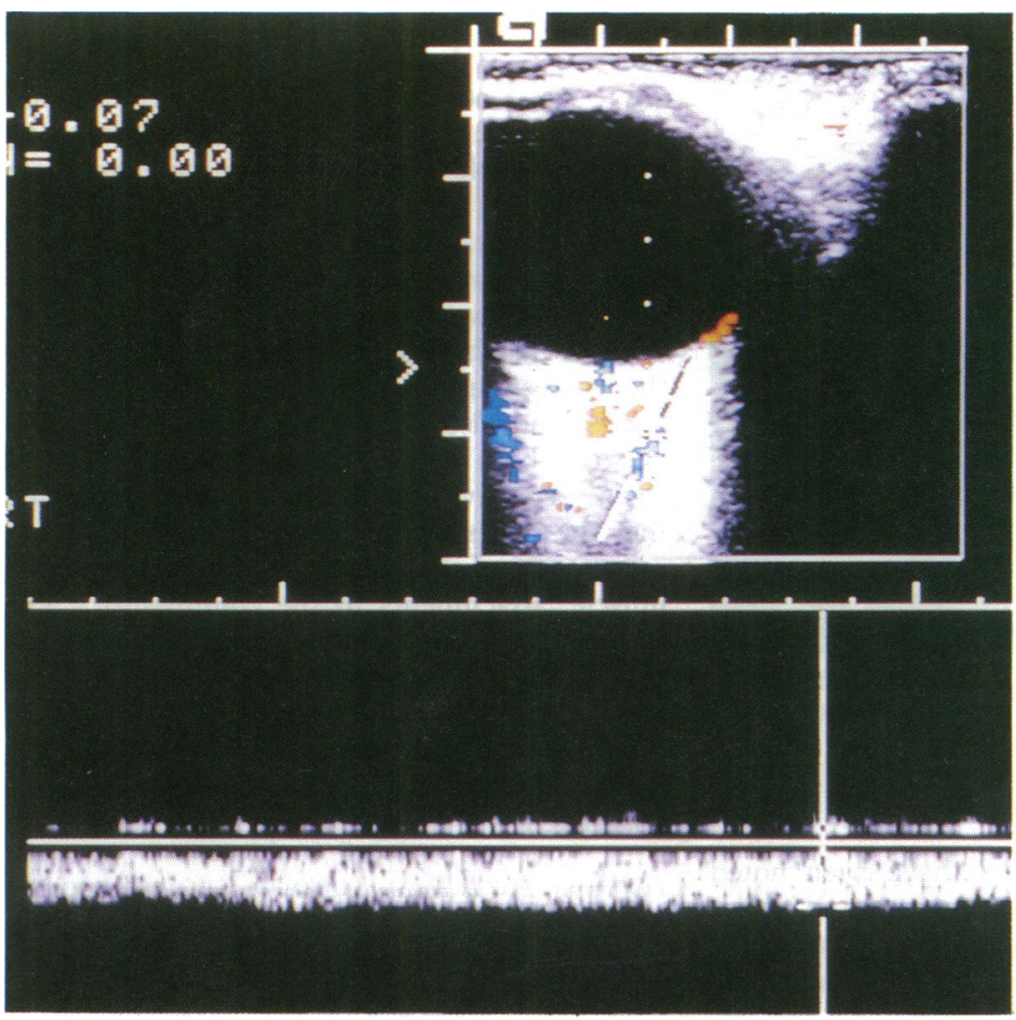

of this pulsation) was $25 \cdot 0 \%$ (SD $18 \cdot 4 \%$ ) compared with $36 \cdot 5 \%(9 \cdot 7 \%)$ in aged-matched controls (significantly different, Mann Whitney $\mathrm{U}$ test, $\mathrm{p}<0 \cdot 001)$.

Work supported by the Scottish Home and Health Dept grant no K MRS $50 \mathrm{C} 1736$.

1 Lieb WE, Cohen SM, Merton DA, Shields JA, Mitchell DG, Goldberg BB. Color Doppler imaging of the eye and orbit. Technique and normal vascular anatomy. Arch Ophthalmo 1991; 109: 527-31.

2 Baxter GM, Williamson TH, McKillop G, Dutton GN. Color Doppler ultrasound of orbital and optic nerve blood flow: effects of posture and timolol 0.5\%. Invest Ophthalmol Vis Sci 1992; 33: 604-10.

3 Taylor AW, Sehu W, Williamson TH, Lee W. Morphometric assessment of the central retinal artery and vein in the optic nerve. Can f Ophthalmol 1993; 28: 320-4.
Department of Health and Community Studies, Chester College, Chester S J Lewis

Department of Anatomy, University of Wales College of Cardiff, Cardiff

H N Tasker

Correspondence to:

Dr Stephen Lewis,

Department of Health and

Community Studies, Chester College, Cheyney Road,

Chester CHI 4BJ.

Accepted for publication

15 June 1994

\section{Mechanism related to the lateral rectus muscle capable of retracting the outer canthus of the eye}

\author{
S J Lewis, H N Tasker
}

Relatively few anomalies of the extrinsic musculature of the human orbit have been identified. Whitnall' believed that this was because 'dissecting room conditions do not favour their identification'. This probably remains true given that the most common teaching entry to the orbital cavity is via the thin supraorbital plates.

\section{Case report}

During detailed dissection of the contents of the orbital cavity, a distinct fibromembranous slip arising from the belly of the left lateral rectus muscle (Fig 1) was discovered in a male subject. The slip ran parallel with the muscle and was attached to the fascia deep to the lateral canthus. A pronounced elevation of the muscle belly was observed associated with the slip's muscular attachment. Muscle fibre arrangement in this elevation suggested that it could not be involved in movement of the eye but would have pulled instead, via the slip, on the outer canthus. There was no separate nerve supply to this elevation; thus, normal contraction of the lateral rectus in abduction of the gaze would have caused a simultaneous pull on the outer canthus. By pulling with forceps to simulate this action, an accompanying retraction of the lateral canthus was observed. This appeared to provide an apparently purposeful, additional action for the lateral rectus in that, while abducting the gaze, it also helped draw the lateral canthus posteriorly, reducing restriction of vision laterally. Although similar fibrous structures were evident contralaterally; as distinct a slip was not found beside the right lateral rectus muscle.

In the absence of material for further detailed dissection, a short study of outer canthus retraction was performed in living subjects asked to follow a pointer moved laterally in the interpupillary plane. $\chi^{2}$ Analysis of the findings (Table 1) suggested no sex difference but that right side retraction was more prevalent (males, $\mathrm{p}=0.019$; females, $\mathrm{p}=0.005$ ).

Table 1 Outer canthus retraction patterns in living subjects

\begin{tabular}{lllllc}
\hline & $\begin{array}{l}\text { Left side } \\
\text { only }\end{array}$ & $\begin{array}{l}\text { Both } \\
\text { sides }\end{array}$ & $\begin{array}{l}\text { Right side } \\
\text { only }\end{array}$ & $\begin{array}{l}\text { Neither } \\
\text { side }\end{array}$ & Totals \\
\hline Males & 7 & 18 & 19 & 34 & 78 \\
Females & 2 & 25 & 13 & 30 & 70 \\
Totals & 9 & 43 & 32 & 64 & 148 \\
\hline
\end{tabular}




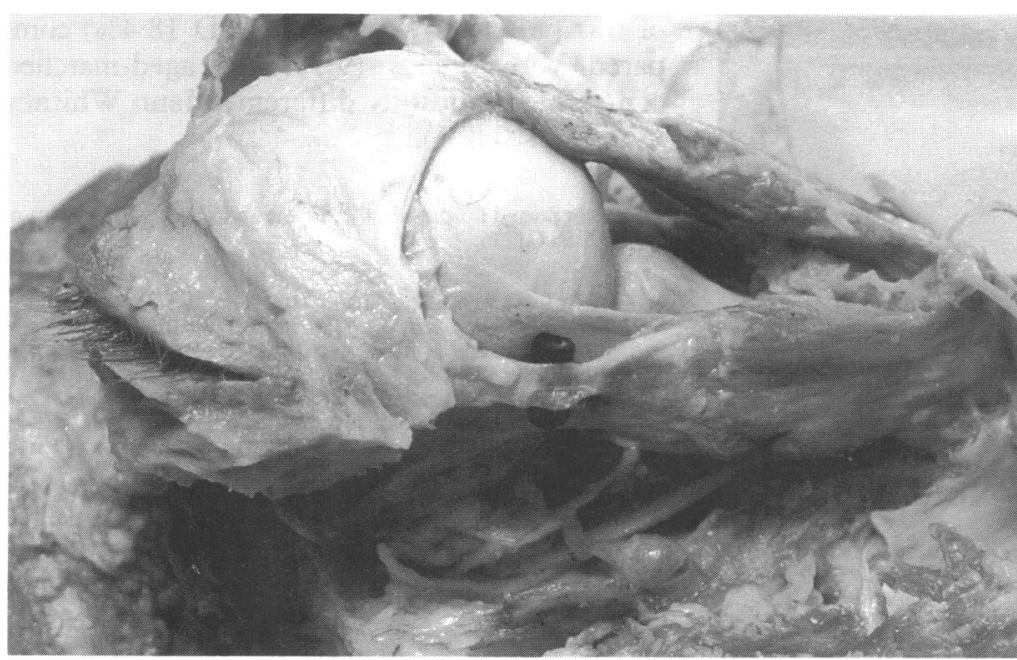

Figure 1 Dissection of a left orbital cavity, viewed from the left anterior aspect, showing a fibrous strip (with marker beneath) arising from the belly of the left lateral rectus muscle and inserting behind the outer canthus.

\section{Comment}

Although muscular fasciculi have been noted passing from the lateral rectus muscle and inserting into the inferior tarsal plate, the lateral wall of the orbit, to the inferior rectus or even the medial rectus, ${ }^{2}$ variation in orbital connective tissue has received less attention. Only quite recently has the role of connective tissue in the orbital cavity begun to be more fully appreciated histologically ${ }^{36}$ such that it is now being considered as an important accessory mechanism involved in eye movement. ${ }^{+6}$ Its arrangement has also been shown to vary between individuals ${ }^{6}$ and bilaterally. ${ }^{+}$As Koornneef ${ }^{5}$ observed, orbital connective tissue 'plays an important, yet to be unravelled, role when normal eye movements are performed'. Connective tissue attachments between lateral rectus muscle and the lateral orbital wall have been described. ${ }^{+}$Whitnall' also described how 'by means of the connections of their fascial sheaths ... the lateral rectus draws the corresponding commissure slightly backwards' and also, when describing the relation between both the medial and lateral recti and their respective check ligaments, commented that the 'recession of parts ... seen on strong movements of the eyeball' was a product of the muscle 'attachments to the commissure'. The fibrous slip described here appears to be related to that mechanism. Although a role in outer canthus retraction is evident, a movement stabilising role whereby the slip might tether the lateral rectus to its lateral relations could also be postulated.

1 Whitnall SE. The anatomy of the human orbit. Oxford: Oxford University Press, 1932: 284-5 and 297.

2 Bergman RA, Thompson SA, Afifi AK, Saadeh FA. Compendium of human anatomic variation. Baltimore: Urban and Schwarzenberg, 1988: 33-4.

3 Koornneef L. Spatial aspects of orbital musculo-fibrous tissue in man. Amsterdam: Swets and Zeitlinger, 1977.

4 Koornneef $\mathrm{L}$. New insights in the human orbital connective tissue. Result of a new anatomical approach. Arch Ophthalmol 1977; $95: 1269-73$.

5 Koornneef L. Orbital septa: anatomy and function. Ophthalmology 1979; 86: 876-80.

6 Koornneef L. Eyelid and orbital fascial attachments and their clinical significance. Eye 1988; 2: 130-4.

\title{
Multiple vortex vein varices masquerading as choroidal secondaries
}

\author{
L da Cruz, B James, R Gray, J Elston
}

Department of
Ophthalmology, Oxford
Eye Hospital, Woodstock
Road, Oxford OX2 6HE
L da Cruz
B James
R Gray
J Elston
Correspondence to:
Dr L da Cruz.
Accepted for publication
1 June 1994

Department of

Ophthalmology, Oxford

Road, Oxford OX2 6HE

J Elston

Dr L da Cruz.

1 June 1994
A woman was investigated for suspected choroidal secondaries because of two smooth masses seen in her right fundus. It was subsequently noted that the size of the masses varied with changes in posture and position of gaze, and they were shown to be vortex vein varices. This case highlights the importance of considering vortex vein varices in the differential diagnosis of fundal masses.

\section{Case report}

A 71-year-old woman presented to the ophthalmic casualty department with sudden onset of floaters and photopsia in her right eye. She had no previous significant ocular history and was otherwise fit and well. On examination it was noted that she had a posterior vitreous detachment, accounting for her symptoms. She also had subretinal masses at 12 o'clock and 2 o'clock (Fig $1 \mathrm{~A}$ and B). Each was about two disc diameters across and was dome shaped. There was no change in overlying retinal detail nor any associated retinal detachment or subretinal effusion. The vitreous was quiet and there was no anterior chamber activity. These masses had not been seen 1 month earlier when the fundus had been examined routinely after a left vitreous detachment. 